\title{
Laporan Kasus: Tatalaksana Median Rhomboid Glossitis Pada Pasien Usia Lanjut
}

\author{
(Case Report: Management of Median Rhomboid Glossitis in Elderly Patient)
}

Ginanjar Hidayatullah', Ayu Mashartini Prihanti²,

${ }^{1}$ Fakultas kedokteran Gigi Universitas Jember

${ }^{2}$ Bagian Penyakit Mulut Fakultas Kedokteran Gigi Universitas Jember

\section{Abstrak}

Median Rhomboid Glossitis (MRG) adalah atropi papila pada bagian tengah dosrsum lidah yang terjadi pada $0,01 \%-0,1 \%$ dari populasi. Median Rhomboid Glossitis diyakini sebagai gangguan perkembangan pembentukan lidah yang terjadi pada pertengahan permukaan dorsum lidah pada pertautan 2/3 anterior dengan 1/3 posterior lidah. Daerah yang mengalami depapillasi merupakan tuberkulum impar yang persisten dan tidak dapat menyatu sepenuhnya dengan bagian lateral lingual dalam perkembangan lidah. Penelitian menunjukkan beragam faktor predisposisi terkait dengan MRG seperti memakai gigi tiruan, merokok, diabetes mellitus, dan infeksi jamur Kandida. Tujuan dari penulisan ini adalah untuk melaporkan tatalaksana kasus MRG pada pasien lanjut usia. Pasien laki-laki 57 tahun datang ke bagian Penyakit MUlut RSGM UNEJ dengan keluhan lidah terasa perih, gambaran klinis intraoral pada dorsum lidah ditemukan atropi papila, rhomboid, eritema, bentuk bulat dengan diameter $\pm 2 \mathrm{~cm}$. Diagnosis akhir pasien tersebut adalah Median Rhomboid Glossitis dengan keterlibatan infeksi Kandida yang ditegakkan dari pemeriksaan subjektif, objektif, serta pemeriksaan penunjang mikologi. Terapi pada kasus tersebut yaitu memberikan obat antijamur nistatin topikal serta multivitamin dengan kandungan B kompleks dan Zink. Pasien MRG dengan keterlibatan infeksi Kandida memberikan hasil positif pada terapi anti jamur nistatin topikal.

Kata Kunci : Infeksi Candida, Median Rhomboid Glossitis, Pasien Lanjut Usia

\section{Abstract}

Median Rhomboid Glossitis (MRG) is papilla atrophy in the middle portion of the tongue which occurs in $0.01 \%$ $0.1 \%$ of the population. Median Rhomboid Glossitis is believed to be a disorder of the development of tongue formation that occurs in the middle of the dorsum surface of the tongue at the $2 / 3$ anterior linkage with $1 / 3$ posterior tongue. The depapillated area is a persistent impregnated tubercle and cannot fully integrate with the lateral lingual in the development of the tongue. Research shows various predisposing factors associated with MRG such as wearing dentures, smoking, diabetes mellitus, and Candida fungal infections. The purpose of this paper was to report the management of MRG cases in elderly patients. 57-year-old male patient came to the Oral Medicine Department RSGM UNEJ with complaints of painful tongue, intraoral clinical features in the dorsum of the tongue found atrophy of papillae, rhomboid, erythema, round shape with a diameter of $\pm 2 \mathrm{~cm}$. The patient's final diagnosis is Median Rhomboid Glossitis with involvement of Candida infection which is established from subjective, objective examination and mycological investigations. Therapy in such cases is to provide topical nystatin antifungal drugs and multivitamins with B complex and zinc content. MRG patients with Candida infection involvement give positive results in topical nystatin antifungal therapy.

Keywords: Candida infections, Elderly Patients, Median Rhomboid Glossitis

Korespondensi (Correspondence) : Ayu Mashartini Prihanti, Bagian Penyakit Mulut, Fakultas Kedokteran Gigi, Universitas Jember. Jl. Kalimantan 37, Jember 68121. Email: ayumashartini@gmail.com

Median Rhomboid Glossitis (MRG) adalah atropi papilla pada bagian tengah dorsum lidah yang terjadi pada $0,01 \%-0,1 \%$ dari populasi.' MRG biasanya lebih sering terjadi pada laki - laki dibandingkan dengan perempuan dengan rasio perbandingan $4: 1.2$ MRG diyakini sebagai gangguan perkembangan pembentukan lidah yang terjadi pada pertengahan permukaan dorsum lidah pada pertautan $2 / 3$ anterior dengan $1 / 3$ posterior lidah. Kondisi ini juga dikenal sebagai central papillary atrophy. MRG diyakini sebagai gangguan perkembangan pembentukan lidah. Daerah yang mengalami depapilasi adalah tuberkulum impar yang persisten yang tidak dapat menyatu sepenuhnya dengan bagian lateral lingual dalam perkembangan lidah sehingga menghasilkan papila yang halus, eritematus, dengan jumlah papila yang lebih sedikit dari keadaan normal. ${ }^{3}$

Beberapa penelitian menunjukkan beragam faktor predisposisi terkait dengan MRG seperti pemakaian gigi tiruan, merokok, diabetes mellitus. ${ }^{4}$ Penelitian terbaru mengungkapkan bahwa MRG yang ada pada dorsum lidah disebabkan karena adanya infeksi jamur kandida pada rongga mulut. Para peneliti menduga bahwa Kandida memiliki peran sebagai faktor penyebab dalam perkembangan MRG.

Dalam pemeriksaan mikologi, spesies Kandida didiagnosis pada $90,0 \%$ pasien MRG. Candida albicans, Candida kefyr, Candida tropicalis, Candida krusei, dan Candida glabrata ditemukan dalam sebagian besar kasus MRG. Median Rhomboid Glossitis, dengan atau tanpa keterlibatan Kandida akan dijumpai area makula kemerahan yang persisten pada lidah pasien karena persistensi 
tuberculum impar, dengan adanya apapilasi di daerah tersebut. Beberapa penelitian tentang MRG mengungkapkan pada 7 bulan setelah terapi, pasien telah bebas dari infeksi Kandida akan tetapi MRG tetap tidak hilang. ${ }^{3,5}$

\section{KASUS}

Pasien laki - laki berumur 57 tahun datang ke Klinik Penyakit Mulut RSGM Universitas Jember pada tanggal 8 Januari 2020 dengan keluhan lidah yang tidak nyaman dan kurang dapat merasakan rasa makanan. Pasien merasakan keluhannya kurang lebih sejak 1 tahun yang lalu. Pasien tidak mengetahui apa penyebab lidahnya terasa tidak nyaman. Pasien belum pernah mengalami gangguan pada rongga mulutnya sebelumnya dan pasien tidak pernah melakukan perawataan apapun untuk menghilangkan rasa tidak nyaman pada lidahnya tersebut. Pasien menggunakan gigi tiruan lepasan sejak kurang lebih 10 tahun yang lalu. Pasien selama ini tidak pernah melepaskan gigi tiruan lepasannya saat tidur. Pasien juga jarang membersihkan gigi tiruan lepasannya.

Pemeriksaan klinis pada ekstraoral pasien tidak ditemukan adanya abnormalitas. Pada pemeriksaan intraoral pasien kehilangan semua giginya (full edountulus ridge) dan menggunakan gigi tiruan lepasan (full denture). Pada dorsum lidah pasien ditemukan apapilasi, eritematus, berbentuk oval dengan permukaan halus, disertai depapilasi pada bagian tepi, ukuran $\pm(3 \mathrm{~cm} x$ $2 \mathrm{~cm})$, batas jelas, di kelilingi pseudomembran putih, dapat dikerok (Gambar 1).

\section{MANAJEMEN KASUS}

Pasien dilakukan pemeriksaan penunjang berupa pemeriksaan mikologi dari hasil oral swab yang dilakukan di dorsum lidah dan didapatkan hasil positif pada spora dan hifa. Dari pemeriksaan penunjang maka dapat ditegakkan diagnosis Median Rhomboid Glossitis disertai oral candidiasis pada dorsum lidah. Terapi yang diberikan pada pasien berupa terapi kausatif menggunakan anti jamur topikal nystatin oral suspension 4 kali sehari $1 \mathrm{ml}$ dan dan multivitamin becomzet 1 kali sehari sesuai anjuran. Pasien juga diinstruksikan untuk membersihkan lidah dengan menggunakan tongue cleaner, melepas gigi tiruan saat tidur, dan rutin membersihkan gigi tiruan.

Pasien kontrol 8 hari setelah kunjungan pertama. Dari hasil anamnesis, pasien mengatakan bahwa rasa tidak nyaman pada lidahnya telah berkurang dan pengecapan pasien sudah mulai membaik, pasien sudah mulai bisa merasakan rasa makanan. Pemeriksaan intra oral pada dorsum lidah masih dijumpai apapilasi eritematus berbentuk oval dengan ukuran $\pm(2 \times 1,5) \mathrm{mm}$ disertai depapilasi pada bagian tepi dan pseudomembran putih (Gambar 2). Pasien diinstruksikan untuk tetap melanjutkan pengobatan nystatin oral suspension dan multivitamin Becomzet, tetap menggunakan pembersih lidah. Selain itu pasien juga tetap diinstruksikan untuk membersihkan gigi tiruan lepasan dan melepaskannya saat tidur kemudian pasien diminta untuk kontrol 4 hari kemudian.

Pasien kontrol 4 hari setelah kontrol kedua, dari anamnesis didapatkan keterangan bahwa rasa tidak nyaman pada lidahnya telah hilang dan pasien sudah bisa merasakan rasa makanan. Pemeriksaan intra oral pada dorsum lidah dijumpai depapilasi berbentuk oval, ukuran $\pm(2 \times 1,5) \mathrm{cm}$, tidak sakit (Gambar 3). Pada pemeriksaan intra oral telah didapatkan perkembangan kesembuhan lesi yang positif dan signifikan pada pasien sejak kunjungan pertama hingga kontrol kedua.

\section{PEMBAHASAN}

Median Rhomboid Glossitis (MRG) diyakini sebagai gangguan perkembangan pembentukan lidah. Daerah yang mengalami depapilasi adalah tuberculum impar yang persisten yang tidak dapat menyatu sepenuhnya dengan bagian lateral lingual dalam perkembangan lidah sehingga menghasilkan papila yang halus, eritematosa, dengan jumlah papilla yang lebih sedikit dari keadaan normal. ${ }^{3}$

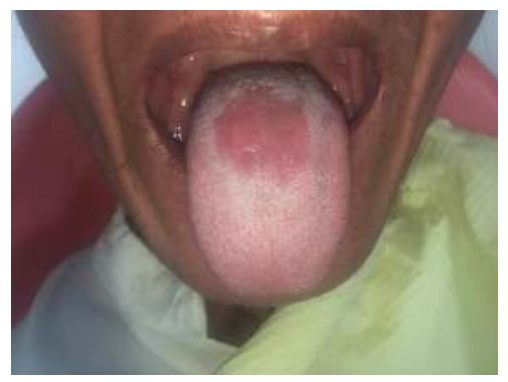

Gambar 1. Kondisi lidah pasien saat pertama kali berkunjung ke RSGM Universitas Jember. 


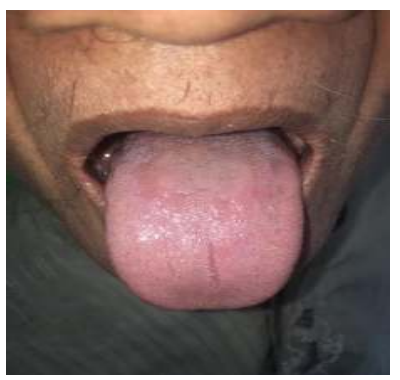

Gambar 2. Kondisi lidah pasien saat kontrol pertama di RSGM Universitas Jember

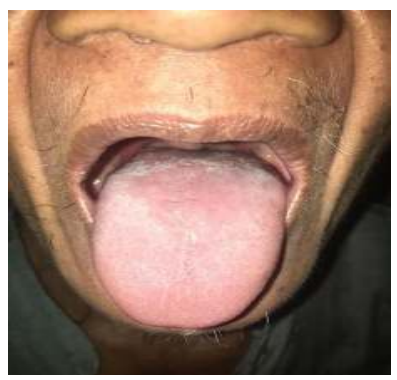

Gambar 3. Kondisi lidah pasien saat kontrol kedua di RSGM Universitas Jember

MRG yang disebabkan oleh karena gangguan pertumbuhan dimana kondisi papila yang tidak dapat terbentuk disebut sebagai Rhomboid. ${ }^{6}$ Permukaan lidah terdiri atas empat jenis papila, yaitu filiform, fungiform, foliate, dan sirkumvalata. Papila papila lidah ini membantu pengunyahan makanan dengan meningkatkan gesekan saat mengunyah. ${ }^{7}$ Papila dapat mengalami perubahan karena berbagai etiologi. Ada empat jenis perubahan seperti eritematosa, apapilasi (tidak adanya papila), atrofi, dan rhoidoid (Nakamura et al., 2017). Perkembangan terbaru mengungkapkan bahwa MRG terjadi karena infeksi Kandida di rongga mulut. ${ }^{4}$

Patogenesis Kandida dimulai pada saat kondisi lingkungan dalam rongga mulut memungkinkan Kandida yang semula oportunistik menjadi patogen, hal ini ditandai dengan peningkatan jumlah Kandida. Sebelum terjadi proses kolonisasi, Kandida terlebih dahulu harus melekat/ adhesi pada dinding sel epitel mukosa rongga mulut. Perlekatan Kandida pada mukosa dibantu oleh enzim Als1p. Als5p, Intlp dan Hwplp. Setelah Kandida berhasil melekat maka Kandida akan melakukan kolonisasi kemudian berlanjut ke tahap selanjutnya adalah invasi. Jamur Kandida dapat melakukan penetrasi ke dalam permukaan epitel mukosa mulut dengan merusak permukaan epitel, hifa Kandida memiliki enzim aspartyl proteinase, enzim ini bersifat dapat melisiskan lapisan epitel rongga mulut sehingga epitel rusak dan Kandida dapat menginvasi lapisan epitel lebih dalam. Dorsum lidah menjadi tempat yang paling sering ditemukan Kandida karena struktur permukaan lidah yang kasar memudahkan untuk menjadi retensi . 8.9
Dari hasil pemeriksaan mikologi didapatkan hasil positif hifa yang menandakan bahwa terjadi infeksi Kandida dalam dorsum lidah pasien. Dari hasil pemeriksaan penunjang mikologi didapatkan kesimpulan diagnosis yaitu terjadi kandidiasis oral pada pasien. Terapi antijamur dengan menggunakan nystatin topikal oral suspensi diberikan karena nystatin merupakan pengobatan lini pertama untuk kasus kandidiasis oral dan sensitif terhadap berbagai jenis Kandida. Nystatin adalah makrolida poliena aktif-membran yang diproduksi oleh strain Streptomyces noursei dan tersedia diberbagai bentuk, seperti suspensi oral, krim topikal, dan pasta. Nistatin tidak dapat diserap oleh saluran gastrointestinal bila diberikan secara oral. Oleh karena itu, penggunaan nistatin topikal dianggap sebagai rute pemberian yang paling umum dalam kedokteran gigi, karena paparan sistemik yang minimal. Nystatin bekerja dengan berikatan pada ergosterol membran sel jamur, sehingga terjadi gangguan pada stuktur membran sel yang menyebabkan kebocoran kandungan intrasel yang berakhir dengan kematian sel. 5

Pasien juga diberikan multivitamin dengan kandungan vitamin $E, C, B 1, B 2, B 6$, B12, asam folat, dan zink. Pemberian multivitamin tersebut sebagai terapi suportif dan berperan sebagai antioksidan dan regenerasi sel, terutama apabila terjadi lesi di mukosa mulut. Pasien diinstruksikan untuk membersihkan lidahnya karena dijumpai coated tongue dengan gambaran klinis pseudomembran yang dapat dikerok.

Pasien dengan Median Rhomboid Glossitis (MRG) disertai infeksi Kandida memberikan respon positif terhadap 
pengobatan dengan Nystatin topikal. Secara klinis terdapat perbaikan lesi pada dorsum lidah pasien MRG, namun bentukan lesi MRG tidak dapat remisi secara sempurna.

\section{DAFTAR PUSTAKA}

1. Joseph BK, Savage NW. Tongue Pathology. Clin Dermatol. 2000; 18: 6138.

2. Goregen $M$, Miloglu O, Buyukkurt MC, Caglayan F, Aktas AE Median rhomboid glossitis: A clinical and microbiological study. Eur J Dent. 201 1; 5: 367-72

3. Panta P, Erugula SR Median rhomboid glossitis-developmental or candidal? Pan Afr Med J. 2015; 21: 221.

4. Mirza D, Raza G, Abassi ZA Median rhomboid glossitis: A peculiar tongue pathology, report of a case and review of literature. Int J Pharm Biol Sci. $2018 ; 6$ : 51-3.
5. Greenberg MS, Glick M, Ship JA. Burket's Oral Medicine. 11th ed. Hamilton: BC Decker Inc, 2008.

6. Nelson BL, Thompson LDR Pathology clinic median rhomboid glossitis. ENTJ. 2017;10: 2-4.

7. Reginato GDS, Bolina CDS, Watanabe I, Ciena AP Three-dimensional aspects of the lingual papillae and their connective tissue cores in the tongue of rats: $A$ scanning electron microscope study. Sci World J. 2014 :1-6.

8. Cawson RE. Essential of Oral Pathology. $7^{\text {th }}$ edition. London: Churchill Livingstone. Elsavier. 2003

9. Gow N a R, Van de Veerdonk, Brown AJP, Netea MG. Candida albicans: Morphogenesis and defence: discriminating invasion from colonization. Nature reviews. Microbiology. 2012. 10(2):112-22. 